\title{
MIR200A Pre-miRNA
}

National Cancer Institute

\section{Source}

National Cancer Institute. MIR200A Pre-miRNA. NCI Thesaurus. Code C82799.

MIR200A pre-miRNA is an oligoribonucleotide that is encoded by the human MIR200A gene and has a role in the regulation of gene expression. 